\title{
issenting narratives of identity in Saami, Meänkieli and Kven literatures
}

\section{Enikô Molnár Bodrogi}

Babeş-Bolyai University, Cluj-Napoca, Email: mbeniko@gmail.com

\begin{abstract}
In this study, I analyse the interconnections between language and identity in the literatures written in minority languages in Fennoscandia (Meänkieli, Saami and Kven). I concentrate on authors who write in their native languages (as well), and who can move between minority and majority language both as ordinary people and as writers. These literatures are small bodies, because there is a small number of people who can still read and write these languages.
\end{abstract}

Minority literatures often deal with the relationship between minority and majority (dominant) cultures describing them by means of power relations. In the minority literatures I am going to deal with past, reconstructed on the horizon of the present, vizualised in a narrative frame, represeting an integral part of the minority writers' great narratives, whose aim is to write their own minority histories, as opposed to the official ones. When examining the works of Fennoscandian minority writers, we can notice many a time that they build their own lifestories into the past recalled for the sake of community.

In my study, I analyse some important elements of the writers' narrative-building. I will be looking for answers for the following questions: What kind of power relations determine the life of the given minorities? How do they relate to different borders in their everyday life? How firm the virtual borders created by minority and majority populations are and what kind of consequences crossing borders has.

\section{Rezumat}

In acest studiu, voi analiza interconexiunile între limbă și identitate, aşa cum apar în literatura fennoscandiană (din Finlanda și Scandinavia), scrisă în limbile minoritare (meänkieli, saami și kvenă). Voi focusa in special asupra acelor autori care scriu (și) în limba lor maternă și posedă dexteritatea de a se mișca liber între limba majoritară și cea minoritară, atât în viața de zi cu $z i$, cât și în calitatea lor de scriitor. Aceste literaturi prezintă corpusuri mici, deoarece sunt relativ puțini cei care mai scriu și citesc în limbile date.

Literaturile minoritare se ocupă deseori de relațiile dintre culturile minoritare și cele majoritare (dominante), oglindindu-le prin relațiile de autoritate. Critica postcolonială este un punct de plecare provocator și captivant în același timp, în ceea ce privește autoritatea și supunerea.

In literaturile minoritare mă voi ocupa de trecutul reconstruit pe orizontul prezentului, vizualizat sub formă narativă, reprezentând parte integrantă a narativei mari ce aparține scriitorilor minoritari al căror țel este să-și scrie propria lor istorie minoritară, în contrast cu cele oficiale. Examinând scriitorii minoritari din Fennoscandia, se poate observa că, în numeroase cazuri, ei încorporează intâmplări personale în trecutul comun, redeșteptându-le de dragul comunității.

Voi analiza în studiul meu elemente importante de construire a narativei, folosite de acești scriitori. De asemenea, voi căuta răspuns la următoarele intrebări: ce fel de relații de autoritate determină minoritățile date; în ce fel se raportează la diferitele granițe, limite în viața de zi cu zi; cât sunt de solide granițele virtuale create de minoritate și majoritate și ce fel de consecvențe atrage încălcarea acestora. 
As the theoretical basis of the lecture is Inceea ce privește bazele teoretice ale prelegerii, voi concerned, I analyise the topic from the analiza subiectul din diferite perspective: studiile perspective of microhistorical research and the postcoloniale, cercetările micro-istorice și studierea psychological study of identity and stigma. psihologică a identității și a stigmei.

Keywords: language minority, language majority, identity, social stigma, narrative

CC BY-SA License (https://creativecommons.org/licenses/by-sa/2.0)

This paper has been presented at the 10th International Conference on Baltic and Nordic Studies in Romania entitled Dissent versus Conformism in the Nordic, Baltic and Black Sea Areas, “Ovidius" University of Constanța, 6-8 June 2019.

The United Nations declared 2019 the year of indigenous languages. In 2016 the Permanent Forum on Indigenous Issues stated that " $40 \%$ of the estimated 6700 languages spoken around the world were in danger of disappearing" ${ }^{\prime 1}$. As languages represent complex systems of knowledge and cultures, their disappearance involve the impoverishment of the global cultural diversity.

In 2018, Johanna Domokos published a book on endangered literatures ${ }^{2}$. It draws attention upon the fact that if a language is endangered, its literary creation is endangered, as well. She notices that the linguistic diversity of the literary field is highly influenced by the real or potential extiction of these languages.

My intention is to dedicate my study to some of those languages and literatures in Scandinavia and Finland, which belong to the endangered group.

\section{Identity as Process}

When attempting to reconcile the multiple definitions of identity, there are at least three typologies calling for consideration. Definitions can be ordered along a dimension between outer and inner polarities. First, at one end, there are those definitions according to which the person's interior (or idiosyncratic inner core) is the source of sameness over time. Secondly, at the other end, there are conceptions of identity which focus on the cultural

\footnotetext{
1 International Year of Indigenous Languages. https://en.iyil2019.org/about/, accessed at 10.3.2019.

2 Johanna Domokos, Endangered Literature. Essays on Translingualism, Interculturality, and Vulnerability (Budapest: Károli Gáspár Református Egyetem - L'Harmattan Publishing, 2018).
} 
and social influences determining who we seem to be to ourselves and to others. Between these two ends, there are the multidimensional conceptions which focus on ongoing dialectical processes between the psychological and the socio-cultural. ${ }^{3}$ I would consider the third of most utility for my own research.

There is no consensus about what the term identity refers to, although it is widely used across different disciplines. For the aims of this study, I focus on certain general aspects of identity. First, the term suggests sameness (idem in Latin) - having characteristics that permit recognition. Second, it implies constancy in the midst of transformation. ${ }^{4}$ I will shortly explain how the experience of constancy is created by means of narrativity. It is important to emphasise that identity is not a static endpoint, but rather a lifelong process of identification. It is dynamic, situational and negotiated. As developmental psychologist Harold D. Grotewant has noted: "one of the most attractive things about the notion of identity is that it looks at the individual in context" ${ }^{\prime \prime}$. The context he is referring to can be of various kinds - historical, political, family (context) and so on.

In describing identity-building processes, we should keep in mind Assmann's ascertainment that identity presumes the existence of further identities. ${ }^{6}$ This implies that whenever we examine identity, we may take into consideration identity-components like ethnic-, linguistic-, religious affiliations, political views, sex and age. They may have different intensities in each case and sometimes, depending on the given case, also their meaning can differ. Some of them are acquired at an early age, have deep roots in us

\footnotetext{
${ }^{3}$ Ruthellen Josselson, "Identity and Relatedness in the Life Cycle", in Identity and Development. An Interdisciplinary Approach, ed. H. A. Bosma et. al. (Thousand Oaks, London, New Delhi: SAGE Publications, International Educational and Professional Publisher, 1994), 98.

${ }^{4}$ Tobi L. G. Graafsma - Harke A. Bosma - Grotevant, Harold D. - David J. De Levita, “Identity and Development. An Interdisciplinary View", in Identity and Development. An Interdisciplinary Approach, ed. H. A. Bosma et. al. (Thousand Oaks, London, New Delhi: SAGE Publications, International Educational and Professional Publisher, 1994), 162.

${ }^{5}$ Harold D. Grotevant - Harke A. Bosma - David J. De Levita - Tobi L. G. Graafsma, "Introduction", in Identity and Development. An Interdisciplinary Approach, ed. H. A. Bosma et. al. (Thousand Oaks, London, New Delhi: SAGE Publications, International Educational and Professional Publisher, 1994), 3.

${ }^{6}$ Jan Assmann, A kulturális emlékezet. Irás, emlékezés és politikai identitás a korai magaskultúrákban (Budapest: Atlantisz, 1999),134.
} 
and awake strong emotional feelings. Others change much easier since they are more superficial. Personal ego is based on narration. This means that we feel as if we had an organic identity from our birth to our death. On the other hand, this is due to the fact that we build the "narrative of the ego" around ourselves. ${ }^{7}$ Csepeli speaks about "autobiographic narrative" and draws attention upon the fact that this narrative meets - in several places - the socio-historic narratives which show the space and time of a life-story. Psycho-social identity is born out of the interaction between these two phenomena. $^{8}$

We should consider identity one of the most important premises of social life. According to this, personal ego is socially constructed from the very beginning, it is formed along continuous social interactions and the individual has to re-determine itself again and again all along its life and together with its own self, also that of others'.

I am going to examine the identity of ethnical and language minorities in my study that is why I consider it important to determine the operative term of ethnic group. By this, I mean such a group which lives together with a (numerical) majority, as well as with other minority groups and which lives with the awareness of belonging together and with the knowledge of common origin, having a common culture and common traditions and their ancestors were speaking the same language.

The term identity, whether individual or collective, inevitably implies a comparative distinction: me versus someone else or us versus them. This comparison involves a process of interpretation regarding the borders between self and other. The essential question for the researcher is thus what makes the individual or group recognizably different.

Difference also means power resource, since being conscious of the given group particularities gives a good basis for building both identity and formulate the aims of the community, as well as determine the actions leading to their fulfillment. On the other hand, there is danger in the fact that we may easily misjudge or discredit those people who are different from

\footnotetext{
${ }^{7}$ Stuart Hall, “A kulturális identitásról”, in Multikulturalizmus, ed. M. Feischmidt (Budapest: Osiris - Láthatatlan Kollégium, 1977), 60-61.

${ }^{8}$ György Csepeli, Szociálpszichológia (Budapest: Osiris. 2006), 521.
} 
"us". ${ }^{9}$ Csepeli words this in the following way: "Minority, as part of the majority society, is actually at the mercy of those stereotypes and categories and preconceptions which are cultivated by mass communication and which they have then to reflect upon themselves." ${ }^{10}$ We tend to determine a minority or a person belonging to that minority by one component of their identity, namely that they belong to the minority. At the same time, we characterise them in stereotypes, that is we homogenise the group. We presume that they have certain features which cannot be seen, but we think they can be deduced. And to all these also those intergroup prejudices are associated which also include the possibility of people unequally being discriminated according to their category affiliation. ${ }^{11}$

According to Barth, an important characteristic of an ethnical group is the border and its maintainance. The group, with its inner determining process signals - both for those belonging to the group and those outside it - who are those they accept and those they do not accept as members of the inner group. "If a group maintains its identity when members interact with others, this entails criteria for determining membership and ways of signalling membership and exclusion."12

Ethnic identity can be a social stigma. In the following chapter I will analyse shortly what stigma means.

\section{Stigma}

For the ancient Greeks, the term stigma referred to "bodily signs designed to expose something unusual and bad about the moral status of the signifier"13. In Christian times, besides this meaning, there were added two more references: first, bodily signs of holy grace, manifesting themselves as

\footnotetext{
${ }^{9}$ Sari Pietikäinen - Hannele Dufva - Sirkka Laihiala-Kankainen, "Kieli, kulttuuri ja identiteetti - ääniä Suomenniemeltä", in Moniääninen Suomi. Kieli, kulttuuri ja identiteetti, ed. S. LaihialaKankainen - S. Pietikäinen - H. Dufva (Jyväskylä: Jyväskylän yliopisto. Soveltavan kielentutkimuksen keskus, 2002), 16-17.

${ }^{10}$ Csepeli 2006, 510.

${ }^{11}$ Ibid. 491.

${ }^{12}$ Fredrik Barth, "Introduction", in Ethnic Groups and Boundaries. The Social Organization of Culture Difference, ed. Fr. Barth (Oslo: Universitetsforlaget, 1994), 15.

${ }^{13}$ Erving Goffmann, "Stigma and Social Identity", in Stigma: Notes on the Management of Spoiled Identity, ed. E. Goffmann (Englewood Cliffs, New Jersey: Prentice-Hall, 1963), 1.
} 
eruptions on the skin, second, bodily signs of physical disorder. Today the term is applied more to the disgrace than to its bodily evidence.

According to Goffman, there are three sharply different types of stigmas: physical deformities, blemishes of individual character (like weak will, domineering passions, rigid beliefs, dishonesty), and the tribal stigma of race, nation, and religion. ${ }^{14}$ All the three are generated in social space and are activated along the interactions. They have the same sociological charcterisics, namely: "an individual who might have been received easily in ordinary social intercourse possesses a trait that can obtrude itself upon attention and turn those of us whom he meets away from him, breaking the claim that his other attributes have on us. He possesses a stigma, an undesired differentness from what we had anticipated". ${ }^{15}$

As we believe that the person with a stigma is a freak, we construct a stigma-ideology to explain his inferiority, and consider him a danger for the society. Such a stigma can be the minority mother tongue of the individual. This exclusionist contempt caused by the mother tongue basically determines the relationship minority - majority, fact which I am going to examine upon real examples in the following chapters of this study.

When a stigmatised person reacts defensively in their interaction with the one who stigmatises them, we tend to consider their behaviour a sign of their imperfection.

"Further, we may perceive his defensive response to his situation as a direct expression of his defect, and then see both defect and response as just retribution for something he or his parents or his tribe did, and hence a justification of the way we treat him."16

In fact, it is understandeable that when interacting with people who discredit the person, (s)he is likely to feel that her/his privacy has been violated, and (s)he may react defensively or even with hostility.

The stigmatised person can respond to situations of contact with stigmatizers in many ways. (S)he might, for example, make an attempt to correct her/his "default" or can see the trials (s)he has suffered as a blessing,

\footnotetext{
${ }^{14}$ Ibid. 3.

${ }^{15}$ Ibid.

${ }^{16}$ Ibid. 4.
} 
because suffering can teach one about life. In case that someone manages to correct the original "fault" (for instance the person belonging to minority learns the majority language), they will look at her/him as at someone who got rid of the stigma and not as at one who had never had it. ${ }^{17}$

In my study, I am going to exemplify the way stigmatised persons relate to those who stigmatise them.

\section{Microhistorical approach}

A microhistorical research is a well demarcated smaller unit - let us say an event or the community of a village or a family or an individual meaning its intensive history examination which, at the same time, from the point of view of its aims means much more than a simple case study. ${ }^{18}$ Referring to Schlumbohm, Szijártó states that microhistorical research "rebuilds the life of everyday people on the bases of ordinary resources by telling and analysing them at the same time." 19 First of all it is by being able to visualise the acting individuals having their own aims and strategies that it gives a new dimension to the historical flow.

Microhistory as a practical researching method is in connection with historical anthropology and it proved to be suitable for intensively studying a well determined smaller topic which takes literary or narrative form. It is suitable, for instance, for researching a topic like the relationship among language, border and identity in minority literatures. Microhistory generally emphasises the acting individual and its intentionality, its posibilities and its space of movement. At the same time, the examination of the individual's microworld is suitable to provide information about its surrounding world and from many points of view, can give important information about the determining society.

Society, as an imagined community, is formed of real individuals. As we have already spoken about it in the chapter dealing with identity these

\footnotetext{
17 Ibid. 6-7.

${ }^{18}$ István M. Szijártó, "A mikrotörténelem”, in Bevezetés a társadalomtörténetbe, ed. Zs. Bódy - J. Ö. Kovács (Budapest: Osiris, 2006), 319.file:///C:/Users/ENIK 1/AppData/Local/Temp/2011_0001_520_bevezetes_a_tarsadalomto rtenetbe.pdf, accessed at 10.3.2019.

${ }^{19}$ Ibid.
} 
individuals are organised into different groups. Both smaller and bigger communities can be imaginary and can unite people even without expecting them to live in the vecinity of one another or to be personally acquainted with one another or to be in direct connection with one another. ${ }^{20}$ In order to be able to describe social groups, it is important to examine their relationships and their network system. We cannot take for granted that people belong to a certain group, neither that the borders between groups are impermeable, exactly the way identity is a dynamic process depending on a situation. It is worth examining the way they create relationships and networks of relationship, as well as those factors that stand at the basis of their solidarity. The Smuggler King's Son, novel written by Bengt Pohjanen, Meänkieli writer, is especially suitable for such an examination.

\section{The Writers}

I use part of the work of five literary writers for analysing the topics of my research.

Bengt Pohjanen (born in 1944) is a multilateral and prolific writer of the Torne Valley and dedicated representative of the Meänkieli literature. He is a Swedish citizen who writes in Meänkieli, Swedish and Finnish. His works include different genres: novels, poems, lyrics, essays, dramas, feuilletons, texts for musicals, short stories. He is the author of the first novel (1985) and the first drama (1987) ever written in Meänkieli. ${ }^{21}$ He is also a translator for nine languages: Swedish, Meänkieli, Finnish, English, German, French, Russian, Livonian and Karelian.

The Norwegian Agnes Eriksen (born in 1951) was working as a teacher in the primary school of Lakselv (Lemmijoki in Norwegian). She has published in Kven books for children, rhymes and rules, and textbooks. She and Eira Söderholm (the author of the first Kven grammar book) won the first Kven language prize in 2017.22

\footnotetext{
${ }^{20}$ Benedict Anderson, Imagined Communities. Reflections on the Origin and Spread of Nationalism (London: Verso, 1983).

21 Enikő M. Bodrogi, “Az anyanyelven alkotás esetlegessége?", in Egyediség és véletlen, Interdiszciplináris párbeszéd 4, ed. K. Veress (Kolozsvár: Egyetemi Műhely Kiadó - Bolyai Társaság, 2016), 109, 111.

${ }^{22}$ Agnes Eriksen, https://nordligefolk.no/kvenene/agnes-eriksen/, accessed at 22.6.2019.
} 
Alf Nilsen-Børsskog (1928-2014) was a trilingual (Kven, Norwegian and North Saami) author who lived in Norway and created the first literary works ever written in the Kven language. He published a series of 4 novels (Life goes on) and five volumes of poems. His novels have had a great ethnopolitical significance for the Kvens. ${ }^{23}$

Rita-Magga Kumpulainen (born in 1953), a Saami writer in Finland, worked as a journalist. She had studied in Finnish at school, and re-learned her mother tongue as an adult. She has started her career at the beginning of our century as a writer after graduating a writers' school.24

Kirste Paltto (born in 1947) is a teacher and a Saami writer from Finland. She was the first woman writer who published her works in Saami. She has been writing lyrical poems, prose, radio plays ever since 1975. She has published more than twenty volumes, and the Finnish state awarded her a lifelong scholarship in $2010 .{ }^{25}$

\section{Mother tongue at home and a foreign language at school}

Language control was also part of the $19^{\text {th }}$ century process of the formation of national states. It was inherent part of the national states legal system. According to language control the language of the sovereign ethnic group was declared language of prestige, then it became a legally sanctioned official language. And one of the aims of the school education, though not admitted still definitly followed, was to strengthen the awareness that certain languages and cultures are more important. than others. ${ }^{26}$

23 Lill Vivian Hansen, 'Alf Nilsen-Børsskogs dikt på net', Ruijan Kaiku 11.16.2017. https://www.ruijan-kaiku.no/alf-nilsen-borsskogs-dikt-pa-nett/, accessed at 22.6.2019.; Anitta Viinikka-Kallinen, "While the wings grow. Finnic minorities writing their existence onto the world map", in Planning a new standard language. Finnic minority languages meet the new millenium, ed. H. Sulkala - H. Mantila, Studica Fennica Linguistica, (Helsinki: SKS, 2010), 165. ${ }^{24}$ Johanna Domokos, "A kötet szerzői és fordítói”, in Finnek_! Multikulturális irodalmi olvasókönyv, ed. J. Domokos (Győr: AmbrooBook, 2013), 380.

${ }^{25}$ Kirste Paltto, “A lappok”, in Lappok, N.-A. Valkeapää - K. Paltto - K. Näkkäläjärvi - Z. Kádár (Budapest: Nap Kiadó, 2014), 104.

${ }^{26}$ Orsolya Nádor, "Kelet-Közép-Európai nyelvpolitikai és anyanyelvi oktatási formák", in Nyelvi jogok, kisebbségek, nyelvpolitika Kelet-Közép-Európában, ed. O. Nádor - L. Szarka (Budapest: Akadémiai Kiadó, 2003), 76. 
School education has probably always been the most efficient political means of language assimilation. In one of her works, SkutnabbKangas makes a thought provoking parallel between the missionary activity of the age of the European colonisation and the more exquisite forms of striving for linguistic assimilation. Still, the missionaries were trying to achieve their goal with the help of Bible translated into the languages of the peoples they wanted to convert while the manuals prepared for the minority groups which were to be "converted" were - or still are - not written in their mother tongues. ${ }^{27}$

As I have earlier noted, minority language is falling under the type of tribal stigma, which may stigmatize its "wearer" even for a whole life. As far as those who speak Meänkieli are concerned, the stereotype is the Swedish majority's notion that the speakers of this Finno-Ugric language are sharply different from the prototype of the Swedish national character ${ }^{28}$, and that they are even ignorant, primitive and uncultured. Around the stigma a different language in our case - they constructed an ideology that explains what an inferior creature the stigmatised person is. This exclusionist disdain has basically determined the relationship between majority and minority not only in Sweden, but also in Norway and Finland.

In the Meänkieli, Saami and Kven literatures, it is when they first go to school to start their studies that children cross the border between the microcommunity of home and family to the macrocommunity of the larger society. In the works of Fennoscandian minority writers who graduated schools in the majority languages, the reader can many a time meet with the language and culture changing role of school. The writers whose works have I analysed used special and - more or less - identical metaphors to picture the feelings of those who were deprived of their mother tongues by the

\footnotetext{
27 Tove Sku[n]tnabb-Kangas, Nyelv, oktatás és a kisebbségek (Budapest: Teleki László Alapítvány, 1997), 6.

28 Anne Heith, "Fluid Identities and the Use of History: The Northern Lights Route and the Writings of Bengt Pohjanen", in Inter: A European Cultural Studies: Conference in Sweden 11-13 June 2007, ed. J. Fornäs - M. Fredriksson (Linköping: Linköping University Electronic Press, 2007), 231-233, http://www.ep.liu.se/ecp/025/ecp07025.pdf, accessed at 23.2.2019; Anne Heith, 'Ethnicity, Cultural Identity and Bordering: A Tornedalian Negro', Folklore 52 (2012): 87-88, http://folklore.ee/folklore/vol52/, accessed at 23.2.2019.
} 
school education. In the next part of my study I will concentrate on the following metaphors faceless, tongueless, stepchild, and dumbness.

\subsection{Faceless}

In her poem ${ }^{29}$ entitled Kasvottoman kansan lapsi (The child of a faceless people), Agnes Eriksen Kven poet expresses the different faces of identity with the help of the mirror, as a symbol. Here you have the poem in Kven and English.

\section{Agnes Eriksen: Kasvottoman Agnes Eriksen: The child of a kansan lapsi faceless people}

Lapsena minula oli peili.

Ko kattoin peilhiin näin

mitä kansa puohais.

Oma kuva näkyi ja perheenki, ämmii ja äijii näkyi.

Raamina oli koko kansan juuret.
As a child I had a mirror.

When I looked in it, I saw

my people working.

I saw my own picture in it and my family's,

my grandmas' and grandpas' as well.

Its frame was my people's roots.

Peilin eessä opettelin puhuhmaan ommaa kieltä, laulahmaan oman kansan äänelä, opettelin ajattelehmaan, olehmaan ihminen.

Seittemän vuotta elin kansan sylissä.
In front of the mirror I learned to speak

my own language,

to sing on my people's voice,

I learned to think, and to be a human.

Seven years I lived in my people's lap.

\footnotetext{
29 Agnes Eriksen,'Kasvottoman kansan lapsi', Arina. Pohjoismainen kveenitutkimuksen aikakausjulkaisu 1 (2002): 104. Transl. by Enikő Molnár Bodrogi, “Identitásőrzés a végeken”, in A komparáció etikája a kritikai vizsgálatokban, Gradus 1, ed. I. Berszán - E. Egyed (Kolozsvár: Babeş-Bolyai Tudományegyetem, A Magyar Irodalomtudományi Tanszék közleményei, 2006), 109-110.
} 
Uusi päivä koitti:

sunnuntai,

pyhäpäivä.

Aamula puhuin vielä meän kieltä, illala ei ennää.

Olin joutunu intternaathiin.

Olin joutunu koulhuun.
A new day was breaking:

a Sunday,

a holiday.

In the morning I still spoke our language,

in the evening not any longer.

I got to a boarding school.

I got to school.

The mirror was broken, the light was switched off, I was kidnapped from my people's lap.

I got a new mirror.

Sain uuen peilin.

Outo kansa siitä kattoi.

Outo laulu siitä kuului.

Kasvoton ja äänetön

haen vieläki.
There was a strange people looking out of it. There was a strange song sounding from it.

Faceless and voiceless, I am still searching.

Translated by Betty Léb

The poem describes the heart-breaking experience of losing one's mother tongue and native culture.

The lyrical ego speaks about two phases of life and school is the demarcating line between them. The first phase is childhood experienced in a mother tongue surrounding, closely connected to the time when she was in a naturally close relation to her family and through it to the past and the culture of her own group. She describes changing with expressions like "new mirror" or the several times repeated "strange" or "the light was switched off", "I was kidnapped". The quick transition between the two life phases is 
shown in a laconic style increasing the dramatic feeling of the situation: one day she was still speaking her mother tongue and on the following day she was not any more.

\subsection{Tongueless}

Bengt Pohjanen's works prove that literature gives the individual a possibility to share in their own people's or ethnic group's culture and collective memory. One of Pohjanen's main aims is to present the relation of the Meänkieli culture to the majority (Swedish and Finnish) cultures. He presents also the individual's experience in sharing the same fate of being different, as well as minority strategies in an exclusionary society.

The trauma of the Swedish assimilation and loss of identity is the central theme of one of Pohjanen's early poems, originally written in Swedish and published in 1973, entitled Jag är född utan språk (Born Tongueless). ${ }^{30}$ Then he himself translated it into Meänkieli and Finnish. Here you have the poem in Meänkieli and English.

\section{Bengt Pohjanen: Kielettömänä Bengt Pohjanen: Born Tongueless syntyny}

Olen kielettömänä syntyny

mykkänä

kieletön paarmuska

katkasi naparihman

Kasusin rajala

kahen kielen traakissa

jonka viimassa

olematon kieleni

mykisty
Tongueless I was born, dumb.

A midwife - tongueless herself cut my funiculus.

I grew up on a frontier; the crossfire of two languages kept cutting, dumbing my tongue.

As I was brought up

\footnotetext{
${ }^{30}$ Bengt Pohjanen, "Att skriva på tre språk", in Den tornedalsfinska litteraturen. Från Kexi till Liksom, ed. B. Pohjanen - K. Johansson (Överkalix: Barents Publisher, 2007), 112.
} 
olheen ihmisiksi

oppimhaan ruottin

ja tunnusthaan kansalisuuen

Minua piiskathiin koulussa

oppimhaan ruottin,

olheen ihmisiksi

kunnon alamaisena

Minua piiskathiin häpeämhään

sitä mikä oli minun ommaa:

kielettömyys

ja raja

Minut rakennethiin

ulkoa päin suunatulla

väkivallala

ja sisäsellä pakola

lyhenyksilä

ja väärinkäsityksillä

Multa otethiin oma lekitimasuuni into a human being,

they warned me

to learn Swedish

and form my national identity.

At school I was rammed

language,

and brought into a good citizen

and subjection.

They rammed in: what's mine -

my being tongueless and

my border-existence

- are shameful.

I have been created

with external violence

internal constraint

deprivations and

misunderstandings.

I was deprived of my identity

Card.

Translated by Betty Léb

The poem tells about being excluded and deprived of identity. The lyrical ego is born "tongueless" because the only accepted language in the given cultural- and social environment is Swedish. Being continuously stigmatised, excluded and humiliated because of his mother tongue, he finishes his poem with the line "I was deprived of my identity/ Card". It logically follows that the one who does not master the "language" does not even exist. 
The discourse of the poem is characterised by lack, alienation, and fragmentation. The reader can easily notice the poem's gloomy tension at rhythm level, as well as the diverging dynamics of poetic and everyday expressions, which perfectly fit the message.

Pohjanen assignes a special significance to this poem. He had it published many a time in different places, translated it, and had it translated into several languages. It can be found right on the opening page of his website $^{31}$ in many languages, like Swedish, Finnish, Meänkieli, Norwegian, Russian, English, Hungarian, Estonian, Greek, and Czech.

In this poem, like in almost all of his works, Pohjanen revolts against accepted norms in the majority language society. He fights for his mother tongue and deconstructs the authority discourse.

\subsection{Stepchild}

In his autobiographical novel The Smuggler King's Son he also writes about the consequences of school education upon the development of a minority child's personality. In Sweden, Selma Lagerlöf's book Nils Holgerson's Wonderful Travels (published in 1906-1907) was used as Geography manual. Its aim was to also strengthen the positive image of the country, increasing by this the children's Swedish identity. According to Pohjanen, Lagerlöf gave exclusively a Swedish identity model, in which the Swedish language and its speakers represent all the inhabitants of the country.

“Everybody has read Selma Lagerlöf's book, »Nils Holgersson's wonderful travels«, at school. Selma received the task of painting the children a comprehensive picture of Sweden from the Swedish school inspectorate, one that mirrors reality. And Selma managed to paint a picture of Swedish reality as it has never existed before, as it doesn't exist today and it never will either. God has always seen us, Nils Holgersson hasn't. And what exactly would he have said to the Swedish about us if he had noticed

\footnotetext{
${ }^{31}$ Bengt Pohjanen's website: http://www.sirillus.se/index bp.htm, accessed at 19.6.2019.
} 
us? It's probably better he hasn't. He might have called us fools like the other Ummikko ${ }^{32}$ did whenever they talked about us." ${ }^{\prime 33}$

In his novel, Pohjanen consciously deconstructs the image offered by the Swedish literature about North-Sweden and those speaking Meänkieli. In reality, they were considered second-rate citizens.

In her work Saamis (1973) Kirste Paltto writes about the injustice against the Saami, about contempt and about the Finnish methods of assimilation into the majority culture. ${ }^{34}$ She starts with her personal experiences in school which determined her future way of thinking about herself and her Saami ethnic group. "As soon as I went to school, I quickly understood that in my beloved Finland, as a Saami girl I can only be a stepchild. Telling the truth, I must admit that the problems I had by then, as a little child, seem to be trifles compared to the ones I lived through later in life. Still, the alienation I experienced as a grown-up started then and there, in that school in Lappland and its Finnish national spirit. [...] I went there to learn - that was my aim. But not even one day had passed and I had to be listening to allusions to the Saamis incivility and backwardness." ${ }^{35}$ In the system of majority language education, she had to learn to be ashamed of her own origin, her own mother tongue and her own nation's special culture. To belong to the Saami ethnical group had meant to be a second-rate citizen in all the three countries - Finland, Sweden and Norway - right until the near past. The new generations are also wearing the stigma of this situation, even if they did not experience what their parents and grandparents did. Suppression of the Saamis is not as direct nowadays as it used to be earlier. It is still going on indirectly as we can find it out from the following quotation, as well: "Many a time I heard that the Saamis have not been oppressed neither in the past nor are they nowadays. Actually, this is true. The Saamis are not flogged and are not taken to prison the way they used to do with the blacks in the United States. Somewhere in the past, they used to

\footnotetext{
${ }^{32}$ A person who speaks only Swedish.

33 Bengt Pohjanen, Jopparikuninkhaan poika (Överkalix: Barents, 2009), 46. All English translations by Betty Léb.

${ }^{34}$ Kirste Paltto, “A lappok”, in Lappok, N.-A. Valkeapää - K. Paltto - K. Näkkäläjärvi - Z. Kádár (Budapest: Nap Kiadó, 2014), 104.

${ }^{35}$ Ibid. 14.
} 
be flogged and even killed. Here, in our area, race suppression is done in a much civilised way. For instance, they hush up even the existance of a whole ethnic group." 36

\subsection{Dumbness and Otherness}

Bitterness and dissappointment and many a time resignation are characteristic for Rita Magga-Kumpulainen's tonality. In the following quotation, she expresses that extrinsic point of view which had also been adopted by her own intrinsic group; namely that one only can succeed in society speaking the language of the majority and that is why it is not worth to transmit the minority language to the children:

"The Saami were made to believe that their language was dying, that there is no need of it and that their mother tongue is not worth anything to be done for it. Their children should better speak Finnish. They may succeed with it and find better jobs. They should become like all the others: they should become Finnish." ${ }^{37}$

She remembers her schooldays as the period when she lost her tongue. The little child, together with many other Saami mates of hers preferred to keep silent instead of being shamed for not speaking the majority language. In Magga-Kumpulainen's writings one can find the tools of a fighting rhetoric (expressions like her words had been "weeded out" of her and thrown into the trash bin; "tear her own tongue out of her mouth"; "violate"; "slave") and lyricism, at the same time.

"My words, my beloved words which were weeded already in my childhood and thrown into the trash bin right at the beginning of school. I hid you whenever I had to. When in visit somewhere, we don't speak the wrong language. It's not allowed. One should preach for everybody to understand it, especially the Finns. When we don't know the proper words, we have to remain silent. If the proper words don't come, we become completely silent. When we are dumb, we cannot harm anyone.

\footnotetext{
${ }^{36}$ Ibid. 15.

37 Rita Magga-Kumpulainen, “Drága anyanyelvem”, in Finnek_! Multikulturális irodalmi olvasókönyv, ed. J. Domokos (Győr: AmbrooBook, 2013), 133.
} 
Only an obedient girl remains. So obedient that she agrees to sell what is dearest for her, to tear her own tongue out of her mouth, to violate her only one. Her mother tongue turns into ashes on the oceans of the world, dust in the rush of life. I was turned into a slave." 38

Because of her stigmatised mother tongue, already as a little pupil she developes an eagerness to get rid of the stigma, to identify with the majority and to be accepted by them so that they consider her one of them. The special Saami culture which differs from the one of the majority, as well as their traditional way of dressing only deepens excommunication. In the following quotation, Magga-Kumpulainen describes the feeling from the point of view of the child.

"They did not notice the little Saami girl. Starting with her first school-year she was mostly living in Finnish surrounding. She had learned the new language and forgotten her own traditions; she wanted foreign clothes. She became like the others, like the Finns." 39

A majority language school is a world completely different from home: the minority tongued children become dumb and are rammed in the awareness of being less valuable. Because of their mother tongue being considered useless by society, children first perceive their own surrounding world as being extruding and alien, later they themselves feel alien and extruded. Nobody wants to be different from the others and children especially long for an accepting safety. And when they cannot find it in a majority language school, their own personality development is affected.

"I was forced to silence. During the first term of my first school-year I was living like in a foreign country, somewhere afar, in the room of mystery-words. I was an alien in the unknown room of traditions. I was scared. I was ashamed. But mostly I was longing. I was missing the wellknown room and the loving talk. I was missing the words warmly coming out of my mother's and my father's mouth, the everyday questions of my little brother, in my own tongue, so that I could understand them and so that everybody could.

\footnotetext{
38 Ibid. 132.

${ }^{39}$ Ibid. 133-134.
} 
I was shy and silent at school. I used to retire into my snail shell better than saying anything. Many a time they laughed at me when my words had a strange sound and were not as correct as those of the others. Then shame came and finally I decided that I did not want to live it through again. If I keep silent I don't do anything wrong and when I speak I have to try it in Finnish." 40

\subsection{Fear and Blemish}

Pohjanen's protagonist, partly autobiographical and partly fictitious, Pänktti, has similar experiences as a Meänkieli child in a Swedish school. In the first morning of his schooldays his mother warns him that he should speak Swedish. Ammi, their schoolmate with whom they go to school together, keeps telling the same thing to him and to Gunnar (called Kynnari in Meänkieli).

"Ammi gestures to us to stay quiet and forbids us to say anything at school on the first day. She mustn't be called Ammi. It's not Swedish and one must speak Swedish at school. I ask her if Pänktti and Kynnari are Swedish, but Ammi only says that we'll see. Alas! I'm so scared." ${ }^{41}$ School as a macroworld compared to the family microworld feels scary to the child, first of all because it functions in another language than he had been used to and because he did not know that language. Soon, in Pänktti's life also comes the period which the Saami Rita also lived through, when he wants to identify himself with his classmates, only that he does this not by forgetting his own mother tongue but by trying to parallelly become a citizen of the majority language world. Learning to write Swedish is a huge effort for him but he knows that this is the price he has to pay for stepping into the world of majority.

"We're having a writing class. The Swedish words are so long and ugly that I need to spell them with my eyes closed and my hands on my ears. I do want to write, but my being doesn't dare. What if I get it wrong! My exercise book is full of red corrections; it's as awful to me as the tup-wool. I mustn't write wrong! Then I'm wrong myself and bad, and mea culpa, mea

\footnotetext{
${ }^{40}$ Ibid. 134.

${ }^{41}$ Pohjanen 2009: 126.
} 
maxima culpa, that's what they say when repenting. I feel a monster, a bastard howling because it lost its way in the forest of emotions and just wants to cry out in the desert of its heart: to hell with it all!" 42

Referring to Goffman's theory, generally, a stigmatised person can react in two ways to her or his own situation. According to one of the strategies, they try to directly mend what stands at the root of their "disability". In case this is possible at all, the result is not necessarily the regaining of a full value, normal status. The ego turns, in fact, from a person wearing a special stigma into a person who is considered to successfully had managed to erase a stigma. The other possible strategy is when the given person is trying to indirectly correct his or her status, making huge efforts, as a private person, to develop the skills in the field questioned. I mean the field generally considered to be closed in front of those who belong to the given disability group. ${ }^{43}$ Those minority Fennoscandian writers who write in the majority languages have chosen this second modality.

Alf Nilsen-Børsskog, remembering his school days, recalls the way his mother tongue had been chased out of there. In his poem, Cantata For a Small People, the poet uses several metaphors to illustrate the way they cast the "dung-words" of his mother tongue upon "frosty bridges" and left them there, completely dissociating themselves from the question whether they survive or not. He expresses with verbs in the passive voice what had happened to his mother tongue and in the following part of the poem he explicitly words that it was the majority language that wanted to "sterilise" the minority one, to deprive it from its fertility. The following verse begins laconically: "No." The picture changes as if after a cutting in a film: the language sentenced to death has survived and it has been spoken over the borders, as well. (This is a reference to the fact that similar dialects are spoken at the nordic borders of Finland. Actually, there is a converse interrelationship here since there was not the Kven language that spread over the borders; there were the speakers of Finnish who brought their

\footnotetext{
42 Ibid. 188-89.

${ }^{43}$ Goffman 1963: 6-7.
} 
language over to Norway.) The poet also personalises the language which seeds itself in people's hearts. ${ }^{4}$

\subsection{Deprived of One's Own Name}

Arbitrarily changing those pupils names who belong to the minority is part of the alien world of the school. This is actually a drastic encroachment of personal rights since one's own name is a determining part of her or his identity. In one of his studies, Jernudd draws attention upon the importance of one's first name in determining one's uniqueness and belonging to a certain group. That is exactly why one of the frequently used strategies of the language- and ethnic assimilation policy was to coerce minority members to use majority names. This may be done even under a refined form, for instance by offering them the use of a majority name, as visible form of belonging to a modern, civilised nation. By this, they can achieve that the marginalised minority does not consider their name change as violation of their human rights but as a right to a unique name. ${ }^{45}$

Magga-Kumpulainen describes the way she became Rita from Aino. Since the little girl has a first- and a middle name the teacher arbitrarily decides that she must use at school that name she had never been called in the microworld of her home. The explanation could even seem acceptable: there are too many children in the class whose name is Aino.

"In the class, teacher Saara repeats the pupils' names. She stops at my name and takes a piece of chalk in her hand.

'Since there are many Ainos in the class, teacher Siiri has decided that from now on we will call Aino Magga - Rita Magga.'

The teacher writes the names RITA then AINO on the blackboard then takes the sponge and erases Aino. Only Rita remains.

'Now, all of you can see that Aino Magga does not exist any more. You too, Aino, know now that we have erased Aino. From now on you are Rita. You cannot be both. Are you sure that you have noted it now?'

\footnotetext{
44 Alf Nilsen-Børsskog, "Kantaatti pienele kansale”, in Poiminttoi, A. Nilsen-Børsskog (Børselv: Kainun instituutti - Kvensk institutt, 2010), 40-41.

45 Björn H, Jernudd, "Personal names and human rights", in Linguistic Human Rights: Overcoming Linguistic Discrimination, ed. T. Skutnabb-Kangas - R. Phillipson - M. Rannut (New York: Mouton de Gruyter, 1995), 130.
} 
What does the teacher want? How could I be Rita? I am Aino. How should I remember that I am somebody else? How can anyone be somebody else the moment they leave home? How could I remember that I am different? Do I completely change if I have a new name, as if I was given the name of the well known evening tale protagonist?" 46

It is also on his first schoolday that Pohjanen's novel-hero has to face the fact that his name does not exist outside the borders of his microworld at home. It is the teacher who first calls him Bengt. Later, he identifies himself with the name so much that he would use it in public communication and he only uses Pänktti in informal medium. He describes things laconically:

"The teacher reads the prayer of Our Father in Swedish and then we sit down. Then she calls the register and, for the first time in my life, I can hear my name in Swedish. It's Bengt and not Pänktti." 47

School years kind of initiate minority children into that macro-world whose borders they must cross in order to be able to succeed in life and to which the only passport is to learn the majority language.

\section{Between Languages and Cultures}

The culture of the peoples examined here is marginalised from two points of view. The cultures of the peoples living in North-Finland, NorthSweden and North-Norway count as minority cultures in themselves compared to the dominating Finnish, Swedish and Norwagian ones. They have different symbols and myths, their version of the language is different, they have different ways of life and even their humour differs from those representing the national culture. At the same time, the culture of the Saami, Meänkieli and Kven inhabitants in the given areas is marginalised compared to the ones of North-Finland, North-Sweden and North-Norway.

\subsection{The Borders of the Minority's Microworld}

Intellectuals in general, and artists in particular, may undertake a double mission of uncovering the historical roots of an ethnic group's

\footnotetext{
${ }^{46}$ Rita Magga-Kumpulainen, Sarvikiela (Tampere: Pilot-kustannus Oy, 2006) 70-71.

${ }^{47}$ Pohjanen 2009: 128.
} 
collective identity, on the one hand, as well as its innermost meaning of ethnic uniqueness in the modern world on the other.

An important part of Pohjanen's activity has been the creation of literature in Meänkieli, which is a genuine representation of Meänmaa. For him Meänmaa (meaning 'Our Land'), populated by Finno-Ugric people is more than a geographical area. At the same time, it means a virtual cultural space constructing an imagined Tornedalian community ${ }^{48}$ with a common identity and a shared Meänkieli cultural heritage.

On the one hand, Meänmaa is a closed world with old traditions and strong religious beliefs, as well as a place of transition, characterised by duality in its values, on the other. I will come back to this topic in subchapter 6.4 .

In the poems of the Kven poet Nilsen-Børsskog there is no effective throughfare between the minority and majority languages and cultures. Those belonging to the majority do not even want to cross the line and a minority member who does cross it would get alienated from her or his own mother tongue world and the majority would accept them only if they identify themselves with it. There exist too much trauma in the minority collective consciousness in order for them to be able to properly value the possibility of crossing the border.

In his poem The Old-Time Village he describes his birthplace as a mysterious see-shore village, rich in historical and fairytale-like memories. Still, it had been mercylessly torn by a language- and geographical border being drawn between families and relatives. This is such an isle of culture which has its own language and which had been decorated with the "pearls of love" by its inhabitants. ${ }^{49}$

\footnotetext{
${ }^{48}$ The Andersonian definition of nation as an imagined community is also applicable to the case of the ethnic minority, in the sense that the members of these groups, while likely never coming to know most of their fellow-members, never meeting or even hearing about them, yet imagine that there is a defined and finite community to which they belong. (Benedict Anderson, Imagined Communities: Reflections on the Origin and Spread of Nationalism. London. 1983: 15)

${ }^{49}$ Alf Nilsen-Børsskog, “Entinen kylä”, in Muiston maila, A. Nilsen-Børsskog (Indre Billefjord: Iđut, 2008), 32-33.
} 


\subsection{Being a Stranger in One's Own Culture and Giving Birth to One's Own Language}

The material I have examined also proves that not only the way out of the microworld and into the macroworld is difficult, but the way back to the culture of their own ethnic group is at least as big a problem. Those who do not use their mother tongue for a long time come to forget their tongue, its usage becomes passive even unwillingly. Even if they understand what others say they cannot communicate. If they go back to their own ethnic group, they feel strangers there and that's how their surrounding consider them. Since they have become unfaithful they are not easily accepted again. Magga-Kumpulainen describes her return as a painful experience:

"When I was talking with relatives, they too seemed to have been smiling at my backward words. They asked me why I did not say things correctly. Did I really not know my so called own mother tongue? Or, perhaps, did I want to be someone else than my own self."50

Pohjanen's hero relates to the language, into which he had been forced as a pupil, to the majority language, with the attitude of an active resistant. He does not want to be a tolerated person, to identify himself according to others' expectations - with a culture alien to him. The aged narrator's retrospective reflections can be found in the quotation here under. He uses the metaphor "deliverer of my own mother tongue" to express that he wants to create his own tongue and to be reborn in it and to build a home in their own mother tongue for others, as well.

"I don't want to be a foreign visitor in other people's reality. I must learn Finnish. Yes: the Finnish we're speaking and which doesn't exist yet, but I'm carrying it in my heart, as if it were an embryo which had been expecting to be born for a long time. But my mind doesn't even grasp that I want to give birth to my mother tongue. Even if I was premature born, I want to be the deliverer of my own mother tongue." 51

\subsection{Mother Tongue, Religion and Subculture}

\footnotetext{
${ }^{50}$ Magga-Kumpulainen 2013: 135.

${ }^{51}$ Pohjanen 2009: 190.
} 
It is their own religion beside their own language that appears in Nilsen-Børsskog's poems as symbols of permanence. No doubt - preserving mother tongue is also supported by the minority religion being different from that of the majority and its language is the one of the community. Both Kven and Meänkieli languages have survived also due to the Lestadian ${ }^{52}$ religion being practically used by them. Still, today, because of the intense language-assimilation the majority language needs to be also used in church.

This is what Nilsen-Børsskog writes in his poem Cantata For a Small People:

"Two gifts we were left

faith and our dear mother tongue." 53

The World War years had a malefic effect upon the culture of the village, including language and religion. Beside financial losses, it also caused losses that could not be made up for ever since: namely linguistic decline. ${ }^{54}$

Mother tongue and faith are also the two dimensions of Pohajnen's sacrality. In order to illustrate the parallelity I am going to cite a short sequence where the reader can also notice his irony (opposed to the Kven poet's tense gloomyness): “We, who were born without a voice, are only richer than the one-language-speaking Ummikkos when approaching God's Realm. Meänkieli is unbelievably rich and accurate when it comes to these things. It fills us with dignity, that's how we become much richer than the Swedish, who have to believe without knowing the language of God's Realm." ${ }^{55}$ Pohjanen gives a positive meaning to the expressions used by the majority discourse to denigrate the Meänkieli language and culture, for instance tongueless (or without voice) and subculture. By using these words in an unusual way, the poet intends to strengthen - inside his own community - the consciousness that they should proudly accept and assume their own

\footnotetext{
${ }^{52}$ Laestadianism came into being in the middle of the 1800s, as a wakening movement inside the Lutheran Church. Nowadays, it still has a lot of followers in North-Europe. Its founder Lars Levi Laestadius (1800-61), was born in Sweden, his father having Swedish, and is mother Saami mother tongue.

${ }^{53}$ Nilsen-Børsskog 2010: 40.

${ }^{54}$ Nilsen-Børsskog 2008: 33.

55 Pohjanen 2009: 26-27.
} 
differentness compared to the majority. "Well, yes, through the centuries, subculture has created the back-doors of resistance. Puns and jokes are quite useful weapons of resistance. And joking is tax-free too." 56

Coming back to Nilsen-Børsskog's poetry, for a Kven, the village is the place of peace and continuity up to the point when those who speak a foreign language break the harmony. ${ }^{57}$ Mother tongue and birthplace are inseparable in Nilsen-Børsskog's poems. The words of the language spoken at home, bearing a strong emotional charge, always resound in his ears wherever he is in the world and remind him of his parents, his grandparents and his siblings. It is his mother tongue that re-creates for him the warmth of home and all the other values he has brought along from the family: love, benignity, quietude - everything he had felt in summer evenings in his surroundings at home. ${ }^{58}$

Domestic shore and bank is the place of recreation and peace both for Nilsen-Børsskog and Pohjanen. Coming home does not only mean a movement in space but also the return of one's thoughts to a well defined place that means home. Let us see an example from both of them:

It is a man's

heart home

Where soul can

get its rest,

Coming home

from

a long journey

With unrest

in his soul. ${ }^{59}$
Forever you'll stay with me,

River flow, my song,

Birch scent and shiny cloud -

Live inside me from now.

I closed you all into my heart,

My river and my mount and my lawn,

You'll be with me on my journeys,

My dear bank, my own home. ${ }^{60}$

\footnotetext{
${ }^{56}$ Ibid. 94.

57 Alf Nilsen-Børsskog, “Alakuloinen taivas", in Poiminttoi, A. Nilsen-Børsskog (Børselv: Kainun instituutti - Kvensk institutt, 2010), 6-7.

58 Alf Nilsen-Børsskog: "Kotitörmän kaunokieli”, in Poiminttoi, A. Nilsen-Børsskog (Børselv: Kainun instituutti - Kvensk institutt, 2010), 28.

59 Alf Nilsen-Børsskog, "Kotitörmiin keđola", in Poiminttoi, A. Nilsen-Børsskog (Børselv: Kainun instituutti - Kvensk institutt, 2010), 32.

${ }^{60}$ Pohjanen Mailmale lähtö. Manuscript.
} 


\subsection{Group-solidarity, leaving and coming back}

As I have already indicated in chapter 3 that Pohjanen's novel, The Smuggler King's Son, is specially appropriate to examine how individuals and social groups build relations and relation systems and what factors are at the bases of their solidarity.

The work includes at the same time the everyday life of a family speaking a minority language and a slice of the social history during the years following World War II, as well as the effect of the cold war upon the thinking of the north-European people.

Basic group facts are the common language and common culture. That is why crossing borders between different language-groups proves to be the most problematic. According to Pohjanen, the majority language speaking world and the minority language speaking world are basically parallel ones: "Those with the Swedish mother tongue have a Swedish world; those who speak Meänkieli have a Meänkieli world. And these worlds can never meet each other." ${ }^{61}$

The common religious values also mean a powerful group-cohesive strength. Those who are members of a religious community other than the majority one take much more seriously the relationship between the spouses, for instance: "In our corner of the world, people still question the possibility of getting divorced just like that, and leaving family behind, the way a cow leaves her pie behind. The old perception of right and wrong still prevails." 62 In subchapter 6.3. I have already mentioned what an important cohesive power religion has inside a given group and a separating function from other religious groups, at the same time.

Groups are consolidated along other criteria, as well. One of them is financial interest which creates the everyday community of customs officers and smugglers. In the Torne Valley border area smugglers were highly esteemed. They were the ones who - besides the prohibited products - also convey forbidden language and culture between those speaking the same language but living in two different countries. At the bases of Pohjanen's

\footnotetext{
${ }^{61}$ Pohjanen 2009: 134.

62 Ibid. 53.
} 
world lies the smuggler philosophy, according to which the political borders are artificially created and urges to be crossed by those who it devides. The representatives of the local authorities are also partners in this: "The smuggler's thoughts never go along borders only over them; the frontier neither means a line nor the czar's pen stroke (because as you know, this border was drawn by chance). It's much more a kind of back-room to him, for people to meet and make deals. They don't sign contracts there, they only shake hands. And where one hand meets another, you can find the frontier's third room, also called the small room of deals. Stamps and pens are nothing but contraband here. And the deal is always personal. It doesn't matter what the deal is, it only matters who it's with. Quite a lot of thought was born here, the border-philosophy..." 63

An analogous interest-group is created by the smuggler and the believer since the later one benefits from the activity of the former one. That is why the believer is willing to indulgently approach certains forms of sin: "And what do the pious say about smuggling? They accept smuggling in the family; the preacher Janne Martiini said that it had no trace of sin. You can get absolution for smuggling for the benefit of your friends; you need to embellish it a little bit, saying that you were too preoccupied with others' sins instead of your own, even shed some tears about how contagious sin could be and how it makes the path to redemption so difficult." ${ }^{64}$ In the pohjanenian world, a lot of things depend on the point of view. This means that it depends on who talks to whom or deals about the given question. The way the author uses personal names also shows whether the community considers someone a member of the inner- or the external circle. The same character, for instance the customs officer is called by Meänkieli speakers on his official name when they see him the representative of the officialities and on his nickname when they share a joke.

The parents of the novel protagonist represent two completely different worlds, still they peacefully live together: "Once you were asking around about me, about my father, the Smugglers' King, about my Christian mother, and about their relationship. I'm not sure I can answer your

\footnotetext{
${ }^{63}$ Ibid. 6.

${ }^{64}$ Ibid. 68-69.
} 
question, but to be honest, in their case they were two completely different people who stuck together, two antithetical perceptions and both of them had their favourite sayings. One of them used to say that you shouldn't be always travelling, looking for trouble right where it dwells; the other one used to say that if you stay at home all the time, trouble will know where to find you. The ideas of travelling and staying at home needed to be harmonised in one way or another." 65

In the presented area, living together still having completely different values and views is not only characteristic for the families' microlevel but also for the level of the macrosociety: "He must have been wondering who could have invented this place where there are so many religious and political sects working, and which otherwise seems to be exactly like a travel agency, where people are coming and going all the time. Each sect has its own political counter-party and each political idea knees a religious ascetic in this windswept wilderness of ours. Against each pilgrim, and there are quite a lot of them around here, stands a hermit who, in his turn, gets drowned into its own ideas of saving the world even if only out of selfesteem. Against each repentant stands one claiming sexual licentiousness, and there stands a convinced atheist against each and every believer. Each story-teller has his own counterfeiter and whenever God builds a church, Satan immediately raises a chapel next to it." 66 This is a context where beside the use of metaphors - repetition has an emphatic role again: it creates an organised form and, on the other hand, it helps the reader to better recognize the language signs that bear added meanings.

Literature researcher Viinikka-Kallinen makes an important statement when she ascertains that in the Fennoscandian literatures leaving home and returning is quite a frequent theme. ${ }^{67}$ The characters (or the lyrical ego in the case of poems) leave home, the circle of their beloved ones, usually in hope of a better life or possibilities of jobs. Later they return home and try

\footnotetext{
${ }^{65}$ Ibid. 56.

${ }^{66}$ Ibid. 148-149.

${ }^{67}$ Anitta Viinikka-Kallinen, “Taistelu sieluista - Identiteetin rakentajat ristiretkellä alueitten Euroopassa", in Tutkielmia vähemmistökielistä Jäämereltä Liivinrantaan, ed. N. Määttä - H. Sulkala, Vähemmistökielten tutkimus- ja koulutusverkoston raportti III. N:o 20, (Oulu: Oulun yliopisto, 2001), 179.
} 
to rebuild their broken relations and find their roots. As I have already mentioned it when speaking about crossing borders between minority and majority cultures, neither direction is easy. Reasons and identity formations may differ, but it is general for the individual to commute between the micro- and macroworld in order to find home for their own soul where they can be full personalities. The dialectics of search is many a time related to real places. The former scene of the protagonist is his birthplace which is far from power centres. The space of his new life is mostly a town which is modern, anonymous and alien. And the way between the two is always long, both geographycally and spiritually.

\section{Closing thoughts: multilocality of the minority writer}

In my study, I was looking for an answer to the following questions: What kind of power relations determine the life of the given minorities? How do they relate to different borders in their everyday life? How firm the virtual borders created by minority and majority populations are and what kind of consequences crossing borders has? At the same time, following the questions, I was trying to unfold the complicated network of the correlation among border, language and identity on the basis of literary texts written in Finno-Ugric languages.

One of the main conclusions of the research is that the minorities living in the Fennoscandian area have been stigmatised because of their mother tongues by those speaking majority languages. There are plenty of examples to this in the examined literary works, as well as to how those belonging to minorities react to the mortifications they have suffered. A certain duality can be noticed: they are loyal to their own language and ethnic group on the one hand and they want to assimilate with the majority, on the other. That is why they interiorise majority language and cultural hierarchy.

On the basis of the text-body examined by me, it is also obvious that preserving and developing minority literary culture in Fennoscandia is in the hands of a few writers. The writer because of the political status of her or his mother tongue, lives in two worlds, speaks the language of two cultures and is generally assimilated into two directions. Their commuting between 
the two worlds and their looking for a ballance is a non-ending process, a form of life and this is what they write again and again covertly or more openly. As stated by Viinikka-Kallinen, illustrating the connection between the two worlds from the point of view of a minority representative is such a challenge that many a time it takes the writer a life-long time to fulfil the task. ${ }^{68}$

Minority writers have to prove themselves into two directions. On the one hand, they have to be believable for those who determine minority rules, and they have to prove to their own communities that they really belong to that given community, on the other. Kirste Paltto, for instance, names as target group both the majority ethnicity and his own minority group: "I have chosen this road to show how difficult it is to be Saami in this society. On the other hand, I want to show to the Saamis that we are not to be blamed for our economic and cultural and legal humiliation." 69

A minority writer becomes part of the Fennoscandian literary institution when she or he manages to get into the circulation of the majority literature. But the majority society generally labels them, mostly as a voice of their own ethnic group, as if their work would only cover one single topic. ${ }^{70}$ From this point of view as well, they have to wear the stigma of their origin, as well as the fact that the official literary discourse accept them only under certain circumstances.

The works examined in this study prove that minorities also need their own narratives in which they can discover themselves, helping by this the cohesion power of their own inner group. From the point of view of the majority which have the political power these seem to obviously be defector narratives. Those belonging to the minority may be helped by literature to find their place in their own history, to laugh at their own humour and to identify their own symbols ${ }^{71}$, while they also can try to pass the borders between the majority and minority groups.

\footnotetext{
${ }^{68}$ Ibid. 172-173.

${ }^{69}$ Paltto 2014: 19.

${ }^{70}$ Viinikka-Kallinen 2010: 149-150.

71 Anitta Viinikka-Kallinen "Kuka kertoo meikäläisistä? Tekstit ja tarinat vähemmistöidentiteetin kantajana", in Tutkielmia vähemmistökielistä Jäämereltä Liivinrantaan,
} 
I consider that Pohjanen's philosophy is very interesting. He says that the political border, with its official bodies is the "demarcation devil", but the human factor, the custom's officer is malleable, "has three eyes: keeps watching with two and turns a blind eye with the third". ${ }^{72}$ That is the border protects and at the same time it tempts to be passed. He considers borders between groups of people quite flexible, except if they are language borders. As I have already shown it, the border between those speaking a minority language and those speaking the majority one can only be crossed in one sense: from the minority towards the majority and its condition is assimilation with majority.

Inger-Mari Aikio-Arianaick, a Saami poet and film director, writes about her experiences concerning the infinity of the effects the different languages and interconnected cultures have upon one another: "From the very beginning, I have been living in a multicultural community. Our home was on the Finnish side of the border between Finland and Norway but all our relatives were living on the other side. There was no border on my mental map. Everything here was part of the Saamiland. Here in the North, Finns and Norwegians and other ethnicities have been living together for long. We were having cultural impact upon one another."73

Still, the mutual impact of cultures and the interoperability among them does not also mean the dialogue of the languages. And until the borders between languages are rigid, a minority writer measures herself or himself in two ways. With one gauge from the point of view of majority and another one from that of the minority. Unavoidably, her or his picture about themselves is affected by the social status of their own language. AikioArianaick for instance feels that she is wearing a mask when belonging to the majority writer community:

"Undeniably, I also underestimate myself when evaluating myself from the position of a Finnish writer, since this is what I have experienced at

ed. M. Mikkonen - H. Sulkala - H. Mantila, Vähemmistökielten tutkimus- ja koulutusverkoston raportti II. N:o 18, (Oulu: Oulun yliopisto, 2001), 280-282.

72 Pohjanen 2009: 6.

${ }^{73}$ Inger-Mari Aikio-Arianaick - Johanna Domokos, „A természet segített abban, hogy jobban megértsem az embereket", in Finnek_ Multikulturális irodalmi olvasókönyv, ed. J. Domokos (Győr: AmbrooBook, 2013), 365-366. 
the level of Finnish society. It affects the picture of myself even unknowingly. It is difficult to feel myself a »real« writer. On the other hand, when I am among Saami writers I do not feel this frustration. Back in a Finnish writer community I notice that I am asseverating again my being a real writer. And others can feel this, as well. So that the mask of a writer I put on can really be felt." ${ }^{\prime 74}$

Thus being stigmatised because of their mother tongue is a common and recurring theme with all the authors. As exclusion and identity crisis caused by it are as well. The only way they can find out of all these is ultimately the return to their own mother tongue and culture, even if it means undertaking a conflict with the majority language and culture.

${ }^{74}$ Ibid 365. 


\section{References:}

Aikio-Arianaick, Inger-Mari - Domokos, Johanna. ' "A természet segített abban, hogy jobban megértsem az embereket".' In Finnek_! Multikulturális irodalmi olvasóköny. Ed. Johanna Domokos. Győr: AmbrooBook, 2013, 363-367.

Anderson, Benedict. Imagined Communities. Reflections on the Origin and Spread of Nationalism. London: Verso, 1983.

Assmann, Jan. A kulturális emlékezet. Írás, emlékezés és politikai identitás a korai magaskultúrákban. Budapest: Atlantisz, 1999.

Barth, Fredrik. 'Introduction.' In Ethnic Groups and Boundaries. The Social Organization of Culture Difference. Ed. Fredrik Barth. Oslo: Universitetsforlaget, 1994, 9-38.

Csepeli, György. Szociálpszichológia. Budapest: Osiris, 2006.

Domokos, Johanna. 'A kötet szerzői és fordítói.' In Finnek_! Multikulturális irodalmi olvasókönyv. Ed. Johanna Domokos. Győr: AmbrooBook, 2013, 377-385.

Domokos, Johanna. Endangered Literature. Essays on Translingualism, Interculturality, and Vulnerability. Budapest: Károli Gáspár Református Egyetem - L'Harmattan Publishing, 2018.

Eriksen, Agnes https://nordligefolk.no/kvenene/agnes-eriksen/, accessed on 22.6.2019.

Eriksen, Agnes. 'Kasvottoman kansan lapsi.' Arina. Pohjoismainen kveenitutkimuksen aikakausjulkaisu 1 (2002): 104.

Goffmann, Erving. 'Stigma and Social Identity.' In Stigma: Notes on the Management of Spoiled Identity. E. Goffmann. Englewood Cliffs, New Jersey: Prentice-Hall, 1963, 1-19.

Graafsma, Tobi L. G. - Bosma, Harke A. - Grotevant, Harold D. - De Levita, David J. 'Identity and Development. An Interdisciplinary View.' In Identity and Development. An Interdisciplinary Approach. Ed. Harke A. Bosma - Tobi L. G. Graafsma et. al. SAGE Publications, Thousand Oaks, London, New Delhi: International Educational and Professional Publisher, 1994, 159-174. 
Grotevant, Harold D. - Bosma, Harke A. - De Levita, David J. - Graafsma,

Tobi L. G. 'Introduction.' In Identity and Development. An Interdisciplinary Approach. Ed. Harke A. Bosma - Tobi L. G. Graafsma et. al. SAGE Publications, Thousand Oaks, London, New Delhi: International Educational and Professional Publisher, 1994, 1-20.

Hall, Stuart. 'A kulturális identitásról.' In Multikulturalizmus. Ed. Margit

Feischmidt. Budapest: Osiris - Láthatatlan Kollégium, 1977, 60-85.

Hansen, Lill Vivian. Alf Nilsen-Børsskogs dikt på net. Ruijan Kaiku 11.16.2017. https://www.ruijan-kaiku.no/alf-nilsen-borsskogs-diktpa-nett/, accessed on 22.6.2019.

Heith, Anne. 'Fluid Identities and the Use of History: The Northern Lights Route and the Writings of Bengt Pohjanen.' In Inter: A European Cultural Studies: Conference in Sweden 11-13 June 2007. Ed. Johan Fornäs, Martin Fredriksson. Linköping: Linköping University Electronic Press, 2007, 227-241. http://www.ep.liu.se/ecp/025/ecp07025.pdf, accessed on 18.6.2019.

Heith, Anne. 'Ethnicity, Cultural Identity and Bordering: A Tornedalian Negro.' Folklore 52 (2012): 85-108, http://folklore.ee/folklore/vol52/, accessed on 18.6.2019.

International Year of Indigenous Languages. https://en.iyil2019.org/about/, accessed on 10.3.2019.

Jernudd, Björn H. 'Personal names and human rights.' In Linguistic Human Rights: Overcoming Linguistic Discrimination. Ed. Tove SkutnabbKangas - Robert Phillipson - Mart Rannut. New York: Mouton de Gruyter, 1995, 121-132.

Josselson, Ruthellen. 'Identity and Relatedness in the Life Cycle.' In Identity and Development. An Interdisciplinary Approach. Ed. Harke A. BosmaTobi L. G.Graafsma et. al. SAGE Publications, Thousand Oaks, London, New Delhi: International Educational and Professional Publisher, 1994, 81-102.

Magga-Kumpulainen, Rita. Sarvikiela. Tampere: Pilot-kustannus Oy, 2006.

Magga-Kumpulainen, Rita. 'Drága anyanyelvem.' In Finnek_! Multikulturális irodalmi olvasóköny. Ed. Johanna Domokos. Győr: AmbrooBook, 2013, 129-135. 
M. Bodrogi, Enikő, 'Az anyanyelven alkotás esetlegessége?' In Egyediség és véletlen, Interdiszciplináris párbeszéd 4. Ed. Károly Veress. Kolozsvár: Egyetemi Műhely Kiadó - Bolyai Társaság, 2016, 103-117.

Molnár Bodrogi, Enikő. 'Identitásőrzés a végeken'. In A komparáció etikája a kritikai vizsgálatokban. Ed. István Berszán - Emese Egyed. Gradus 1. Kolozsvár: Babeş-Bolyai Tudományegyetem, A Magyar Irodalomtudományi Tanszék közleményei, 2006, 99-110.

Nádor, Orsolya. 'Kelet-Közép-Európai nyelvpolitikai és anyanyelvi oktatási formák.' In Nyelvi jogok, kisebbségek, nyelvpolitika Kelet-KözépEurópában. Ed. Orsolya Nádor - László Szarka. Budapest: Akadémiai Kiadó, 2003, 76-90.

Nilsen-Børsskog, Alf. 'Entinen kylä.' In Muiston maila. Alf Nilsen-Børsskog. Indre Billefjord: Iđut, 2008, 32-34.

Nilsen-Børsskog, Alf. 'Kantaatti pienele kansale.' In Poiminttoi. Alf NilsenBørsskog. Børselv: Kainun instituutti - Kvensk institutt, 2010, 35-41.

Nilsen-Børsskog, Alf. 'Alakuloinen taivas.' In Poiminttoi. Alf NilsenBørsskog. Børselv: Kainun instituutti - Kvensk institutt, 2010, 5-8.

Nilsen-Børsskog, Alf. 'Kotitörmän kaunokieli.' In Poiminttoi. Alf NilsenBørsskog. Børselv: Kainun instituutti - Kvensk institutt, 2010, 28-30.

Paltto, Kirste. 'A lappok.' In Lappok. Nils-Aslak Valkeapää - Kirste Paltto Klemetti Näkkäläjärvi - Zoltán Kádár. Budapest: Nap Kiadó, 2014, 14-105.

Pietikäinen, Sari - Dufva, Hannele - Laihiala-Kankainen, Sirkka. 'Kieli, kulttuuri ja identiteetti - ääniä Suomenniemeltä.' In Moniääninen Suomi. Kieli, kulttuuri ja identiteetti. Ed. Sirkka Laihiala-Kankainen Sari Pietikäinen - Hannele Dufva. Jyväskylä: Jyväskylän yliopisto. Soveltavan kielentutkimuksen keskus, 2002, 9-20.

Pohjanen, Bengt. 'Att skriva på tre språk.' In Den tornedalsfinska litteraturen I.

Från Kexi till Liksom. Bengt Pohjanen - Kirsti Johansson. Överkalix: Barents, 2007, 112-126.

Pohjanen, Bengt. Jopparikuninkhaan poika. Överkalix: Barents, 2009.

Pohjanen, Bengt website http://www.sirillus.se/index bp.htm, accessed on 19.6.2019. 
Sku[n]tnabb-Kangas, Tove. Nyelv, oktatás és a kisebbségek. Budapest: Teleki László Alapítvány, 1997.

Szijártó, M. István. 'A mikrotörténelem'. In Bevezetés a társadalomtörténetbe. Ed. Zsombor Bódy- József Ö. Kovács. Budapest: Osiris, 2006. https://www.tankonyvtar.hu/hu/tartalom/tamop425/2011_0001_520 _bevezetes_a_tarsadalomtortenetbe/ch05s04.html, accessed on 24.6.2019.

Viinikka-Kallinen, Anitta. 'Kuka kertoo meikäläisistä? Tekstit ja tarinat vähemmistöidentiteetin kantajana.' In Tutkielmia vähemmistökielistä Jäämereltä Liivinrantaan. Ed. Miia Mikkonen - Helena Sulkala - Harri Mantila, Vähemmistökielten tutkimus- ja koulutusverkoston raportti II. N:o 18, Oulu: Oulun yliopisto, 2001, 275-286.

Viinikka-Kallinen, Anitta. 'Taistelu sieluista - Identiteetin rakentajat ristiretkellä alueitten Euroopassa.' In Tutkielmia vähemmistökielistä Jäämereltä Liivinrantaan. Ed. Niina Määttä - Helena Sulkala, Vähemmistökielten tutkimus- ja koulutusverkoston raportti III. N:o 20, Oulu: Oulun yliopisto, 2001, 169-181.

Viinikka-Kallinen, Anitta. 'While the wings grow. Finnic minorities writing their existence onto the world map.' In Planning a new standard language. Finnic minority languages meet the new millennium. Ed. Helena Sulkala - Harri Mantila, Studica Fennica Linguistica, Helsinki: SKS, 2010, 147-177. 